overarching dialogue. The accessible language, clear and comprehensible argumentation, tackling of timely subjects, and inclusion of numerous practical suggestions are likely to ensure a wide readership for this edited volume, one that will include students, future and current teachers, scholars, parents, and anyone interested in the latest developments in EYL.

Nada Kujundžić

\title{
Girlhood History in Book Series
}

LuElla D'Amico, ed. 2016. Girls' Series Fiction and American Popular Culture. London: Lexington Books. 297 pp. ISBN 978-1-4985-1762-1

DOI: $10.21066 /$ carcl.libri.2017-06(01).0009

Girls'Series Fiction and American Popular Culture is the first title in a series of books called Children and Youth in Popular Culture, which features works that reflect on the different ways in which children and young people are portrayed in popular culture. This is an international series which recognises how literature that features children and young people shapes readers. The main topics in the book range from gender, race, and class to religion, law, and other themes.

The editor, LuElla D'Amico, is Assistant Professor of English and Director of the Women's and Gender Studies program at Whitworth University in Washington. She specialises in early and nineteenth-century American literature, with special focus on girlhood studies, women's writing, and young adult fiction - all themes that this book explores.

This book is an edited volume which examines changes in the characters of young women in American popular culture during the last 150 years. The authors focus on book series, an important part of American history, which had a particular effect on young girls. The introductory section of the book posits that book series helped young American women define how they wanted people to perceive them and assisted them in grasping the cultural demands put upon them.

Divided into fourteen chronologically organised chapters, the volume incorporates series such as Katy, Five Little Peppers, Nancy Drew, Trixie Belden, Betsy-Tacy, The BabySitters Club, ending with chapters about the Vampire Academy series and Pretty Little Liars. The chronological organisation helps the reader see the evolution of young American girlhood through popular book series, and splendidly shows the aim of this collection, which is to offer the reader both a historical context and an analysis of the girls' series genre.

The volume starts with Marlowe Daly-Galeano's contribution “Louisa May Alcott's Theater of Time". Although it is said here that the publishing of Louisa M. Alcott's Little Women in 1868 was a defining moment for girls' book series in gaining recognition, the character of Nancy Drew, a girl sleuth, is referred to by many authors in their chapters. Nancy Drew is said to be a perfect character in terms of moral identity, with no need to change or grow in any way. Characters such as Trixie Belden (Michael G. Cornelius' "Nancy Drew's Shadow: Trixie Belden and a Case for Imperfection"; Carolyn Cocca's "The Bob-Whites of the Belden-Wheeler Detective Agency: Gender, Class, and Race in the Trixie Belden Series, 1948-1986"; Nichole Bogarosh's "Nancy Drew and Trixie Belden: Girl Detectives, Role Models, and Feminist Icons") show young girls that growth and change are important in reaching one's final destination in life. The character of Trixie Belden also serves to 
show that being a tomboy, or being intelligent and independent, is something to be proud of, which was one of the goals of second-wave feminists. Trixie Belden is important to put an end to the message that women are just sexual objects, which had consistently been promoted by the media. In the chapter "The Value of Girl Labor in the Five Little Peppers Book Series", Christiane E. Farnan writes about how the work ethic was used in the series to measure the value of a girl, by placing hard-working girls at the top of the hierarchy. This instils in young girls the idea that hard work is important and will pay off. Another chapter which encourages young girls to contemplate their status in society is Paige Gray's "A Spectacle of Girls: L. Frank Baum, Women Reporters, and the Man Behind the Screen in Early Twentieth-Century America", which argues that Baum's series The Wonderful Wizard of $\mathrm{Oz}$ and Aunt Jane's Nieces challenged the gender ideology of the early twentieth century by exploring women's position and their roles in their public and private lives.

Another topic the book touches upon is disability. In Eva Lupold's chapter about the Katy series, the author writes about how the theme of disability was used to both promote heteronormative plots and disrupt conceptions of beauty, while emotional behaviour was equal to queerness and unsustainability. Further, she argues that talking about emotions is crucial to understand the relationship between disability and girls in series fiction.

The chapters "Female Heroines and Third-Wave Feminism in the Vampire Academy Series" by Janine J. Darragh and "Pretty Little Liars and Their Pretty Little Devices" by Grace Halden discuss young girls and women who represent many cultural backgrounds and break stereotypical gender roles, an objective of third-wave feminists. These series tell young girls that it is acceptable to have multiple emotions and desires, which sometimes might be contradictory, and that today's women can be whatever they want to be. Previous series had been influenced by second-wave feminism, seen in the tendency to show the importance of fighting for equality and political rights. The influence of second-wave feminism, which showed that women have the same rights as men, is seen in the fact that girls become main characters and are shown doing the same things as boys, thus disrupting traditional gender roles. The Vampire Academy series expands on this to include women of all ethnicities, orientations, economic statuses, etc. In Grace Halden's chapter about the Pretty Little Liars series, we are introduced to technology used as a bullying device. Pretty Little Liars tackles issues such as anxiety, insecurities about body image and grades, all vital parts of girls' lives today.

This well-researched volume provides an insightful and informative look into a part of the history of girls' series in American popular culture. It is well-structured and organised to help the reader understand the subject. This book has much to recommend it to its readers, especially teachers and students who want to inform themselves about series for young girls and boys, and the messages they provide. What adds to the success of this book is that it covers a wide range of girls' series and offers a look into the progress of women's rights, as well as a view into the popular culture of the last century. This volume also manages to connect characters from different series and draw comparisons between them, which contributes to developing a new and educational perspective on girls' series. 